\title{
5. 神経内視鏡手術のトレーニング
}

埼玉医科大学脳神経外科

石原正一郎

現在，各科における内視鏡治療に関する認定制度，トレー ニングシステムが確立している中で, 神経内視鏡治療に関し てはこれらがまだ整備されていないのが現状である。しかし 近年神経内視鏡手術による合併症例や治療困難例も報告さ れ，いま正に適切な方向性とトレーニングシステムの必要性 が求められている。これまでに国内において企画，参加した 神経内視鏡実習トレーニングは約 20 回を超えたが, 主に cadaver brain を用い, 使用機器に関する理解や手術中の解剖 や術式などにつき研修している。.またオーストラリア, 中国, ブラジル，フランス，アメリカなどの諸外国においてもハン ズオンコース, 実習コースなどに参加し, 指導を行ってきた。 顕微鏡手術に慣れている脳神経外科医にとって，内視鏡下で の手術は見た目に容易に感じる傾向があるが，受講者の多く が，予想より難しいとの感想を持っており，このような基礎 的トレーニングの意味を痛感している. 今回これらの経験を 振り返り，より安全な神経内視鏡手術を目指すためのトレー ニングシステムにつき考察したい.

\section{6. 神経内視鏡手術施行にあたってのガイドライン と技術認定制度について}

慈恵大学病院総合母子健康医療センター小児脳神経外 科，日本神経内視鏡学会ワーキング委員会

森宏

神経内視鏡手術はビデオモニター画面上の二次元画像をみ ながら行う手術であり,特殊な手術手技の習得が必要である。 日本神経内視鏡学会では, 安全な神経内視鏡手術の普及を目 的に, 神経内視鏡手術施行にあたってのガイドラインと, 技 術認定制度を発足させるべく準備を進めてきた。ガイドライ ンに関しては，神経内視鏡を用いて行う手術全般に共通する トレーニングの minimal requirement を示し, 経験豊かな指導 者の下で施行することを针告し，独立した術者としての条件 (助手として 10 例以上, 術者として指導者の下で 10 例以上) も明示した．したがって神経内視鏡手術を行うことができる 医師を規制するものではない，技術認定制度に関しては，独 立した術者としての条件をクリアした後，一定の技術レベル に達した者を認定するものである。対象手術手技は，(1)第三 脳室底開空術・生検術を含む脳室・震胞内手術, (2)経蝶形骨 洞手術, (3)脳内血腫吸引術, (4)神経内視鏡補助顕微鏡手術,

(5)その他の脳内視鏡手術とし，(1)に関しては今後別途部門認 定医を制定する予定である。 